\title{
The impact of cardiovascular drugs on the efficacy of local anesthesia in dentistry
}

\author{
Marko J. Milosavljevic ${ }^{a}$, Slobodan M. Jankovic ${ }^{b}$
}

Background and Aim. Drugs used chronically by patients with diseases of the cardiovascular system (group C of the ATC classification) may act on adrenergic receptors and/or certain ion channels, which gives them the potential to interact with the action of local dental anesthetics. The aim of the study was to investigate the effect of systemically administered chronic cardiovascular medication (oral route) on the efficacy of intraoral local anesthesia in patients with diseases of the cardiovascular system.

Patients and Methods. This was a prospective cohort study which analyzed the efficacy of local terminal anesthesia (onset of anesthesia, duration anesthetized area) in the upper jaw of 70 patients: 40 patients on medication for cardiovascular system disorders and 30 patients who were not using these drugs (the control group). The following cardiovascular drugs were used: beta blockers, angiotensin converting enzyme inhibitors, calcium channel blockers, vasodilatators, diuretics, angiotensin receptor blockers, antiarrhythmics, statins and alfa blockers.

Results. The onset of anesthesia on the vestibular side was faster in those taking cardiovascular drugs ( $40.50 \pm 19.87 \mathrm{~s})$ than the control patients $(58.93 \pm 31.07 \mathrm{~s} ; P=0.004)$ and duration of anesthesia on this side was shorter. Although the difference was not significant, it was evident that on vestibular and palatal side the anesthetized area was more rapidly reduced in the patients taking cardiovascular drugs. The duration of cardiovascular therapy also had a significant impact on the anesthetized area.

Conclusion. Drugs acting on cardiovascular system may influence the effect of local anesthetics used in dentistry, possibly through interaction with autonomic receptors and ion channels.

Key words: dental anesthesia, local anesthesia, beta blockers, cardiovascular agents, calcium channel blockers

Received: April 27, 2016; Accepted with revision: July 21, 2016; Available online: August 2, 2016 http://dx.doi.org/10.5507/bp.2016.040

${ }^{a}$ Department of Dentistry, Faculty of Medical Sciences, University of Kragujevac, Serbia ${ }^{b}$ Department of Pharmacology, Faculty of Medical Sciences, University of Kragujevac and Clinical Center Kragujevac, Serbia Corresponding author: Marko J. Milosavljevic, e-mail:drm.milosavljevic@yahoo.com

\section{INTRODUCTION}

Local anesthetics, the most commonly used drugs in dental practice, are administered in order to prevent pain during dental procedures. They they can also be administered for diagnostic purposes to determine the origin of pain in the area of the face and jaw. It is well known that local anesthetics reversibly block conductivity of electrical impulses in nerves by suppressing voltage-gated sodium channels, without any damage to the nerves ${ }^{1}$.

Articaine is an efficient local anesthetic with one of the best safety profiles of the available drugs for these purposes. A molecule of articaine includes an aromatic thiophene ring and also an aromatic methoxycarbonyl substituent in contrast to other amide-type local anesthetics. The aromatic parts of the molecule increase the lipophilicity of articaine in comparison to other amino amide local anesthetics, and ensure penetration of articaine to bone and other tissues ${ }^{2}$. The high lipophilicity of articaine is responsible for its better performance than lidocaine during local anesthesia of mandibular and maxillary posterior teeth by buccal infiltration ${ }^{3}$. Articaine with lower concentration of epinephrine $(1: 200,000)$ compared to articaine with higher concentration of epinephrine $(1: 100,000)$ evokes less stimulation of the cardiovascular system and is recommended for patients with cardiovascular diseases ${ }^{4}$.

Patients with chronic diseases of the cardiovascular system are often encountered in dental practice. Sudden elevation of catecholamines in blood, which occurs as a result of inadequately managed pain or fear during dental intervention could have adverse consequences for these patients, and therefore prevention should be ensured by proper local anesthesia. The drugs used chronically by patients with diseases of the cardiovascular system may act on adrenergic receptors or ion channels, which gives them potential to interact with the action of local anesthetics ${ }^{5}$. This is especially true for some antihypertensive drugs which in high concentrations may block the permeability of the sodium channel and cause local anesthetic action ${ }^{6}$. However, local anesthetics themselves may show cardiac toxicity when used for dental anesthesia in patients with cardiovascular diseases: ST segment depression was noted in $11 \%$ and elevated levels of myocardial enzymes in $7 \%$ of patients with cardiopathy, who were anesthetized by mepivacaine without vasoconstrictor ${ }^{7}$.

The aim of our study was to investigate the influence of systemically administered chronic cardiovascular medication (oral route) on the efficacy of intraoral local anesthesia in patients with diseases of the cardiovascular system. 


\section{PATIENTS AND METHODS}

\section{Study design}

The study was approved by the Ethics Committee of the Faculty of Medical Sciences in Kragujevac under no. 01-3206 from May the $11^{\text {th }}, 2012$. It was conducted at dental practices of the Faculty of Medical Sciences in Kragujevac, Serbia, during the period from November 2012 to March 2015. All patients who participated signed the informed consent.

The study was designed as a prospective cohort study, which analyzed the efficacy of local terminal anesthesia in the upper jaw of 70 patients (40 patients using drugs for cardiovascular system disorders (cohort taking cardiovascular drugs /CVDs/) and 30 patients who were not using these drugs (control cohort). The patients were 20 to 65 years old and they had no contraindications for administration of local anesthesia according to the official summaries of product characteristics of the anesthetics used in the study. Before setting the indications for tooth extraction under local anesthesia the medical history of all patients was obtained, as well as the data on cardiovascular drugs they were taking (the number of cardiovascular drugs, name of the drug, the subgroup of cardiovascular drugs, the daily dose and for how long it had been used by the patient). All patients had their body mass index calculated and they were classified on the basis of this index into one of four groups.

\section{Inclusion and exclusion criteria}

After complete of dental examination, all patients who needed extraction of the teeth in the upper jaw (region between the second premolars) were included in the study. Patients scheduled for the extraction of teeth had to meet the following criteria: patients using drugs for cardiovascular system disorders (group C of the ATC classification), teeth in the upper jaw in the region between the second premolars had to have periodontal disease, chronic periapical lesions without possible endodontic treatment and residual roots of teeth that could not be adequately endodontically treated.

The criteria for exclusion of subjects from the study were: patients with other systemic disease (diabetes mellitus, COPD, bronchial asthma, hyperthyreosis, etc.), patients with infections in the orofacial area, patients who were known to be sensitive or allergic on articaine or same ingredients in local anesthetic, those who had dental intervention with the use of local anesthesia in the past $48 \mathrm{~h}$, patients who had used analgesics in the past seven days, pregnant women, nursing mothers and children under 18.

\section{Study protocol}

Local anesthesia was achieved in all patients by the following dose of $4 \%$ articaine with epinephrine 1:200,000 (Ubistesin, 3M Espe Germany):

1. $1.4 \mathrm{~mL}$ of anesthetic solution was injected from vestibular side for $30 \mathrm{~s}$ in the projection of the tooth root tip planned for extraction.

2. $0.3 \mathrm{~mL}$ anesthetic solution was injected from the palatal side for $30 \mathrm{~s}$ in the projection of the tooth for extraction.

The anesthetic was administered by syringe (Pluraject 2, 3M Espe, St. Paul, MN, USA) and $30 \mathrm{G}$ needle (Septodont ${ }^{\circledR}$, Dental Needle, Guyancourt, France). The anesthetic procedures were performed always by the same dentist who was not involved in the study as a researcher.

The time to onset of anesthesia was measured by pinprick testing using a sterile, short $27 \mathrm{G}$ needle (Medoject, Chirana T, Slovak Republic), always in the same time intervals of $30 \mathrm{~s}\left(\right.$ ref. $\left.^{8}\right)$. Pinprick testing involved direct contact between the needle and bone periosteum that caused a sharp pain if the anesthetic was not yet acting. The effect of local anesthesia was determined as pain absence or blunt sensation being felt after pin prick.

The duration of anesthesia was checked at 10-min intervals, starting from the tenth minute after its onset, by the same pin-prick testing. The anesthetized area was also measured by the pin-prick method at the $10^{\text {th }}, 30^{\text {th }}$ and $60^{\text {th }}$ min from the vestibular side and at the $10^{\text {th }}$, $30^{\text {th }}$ and $40^{\text {th }}$ min from the palatal side after the onset of local anesthesia. The anesthetized area was marked by a non-toxic red ink pencil and measured by the orthodontic nonius (Fig. 1). The measured distances were expressed in milimeters.

\section{Power of the study}

In order to achieve statistical power minimum $80 \%$ and probability of type I statistical error less than 0.05 , with expected difference in duration of local anesthesia of $0.665 \mathrm{~min}$ (ref. ${ }^{9}$ ), we calculated by G Power 3.1 software $^{10}$ that using the Student's t-test we would need at least 37 patients per group.

\section{Statistical analysis}

The statistical analysis was performed by the standard software package SPSS, version 18.0. Continuous variables are presented as means \pm standard deviation (SD) or categorized as frequencies. For comparison of mean values of continuous variables, the Student's t-test for independent samples or Mann Whitney U test was used, de-

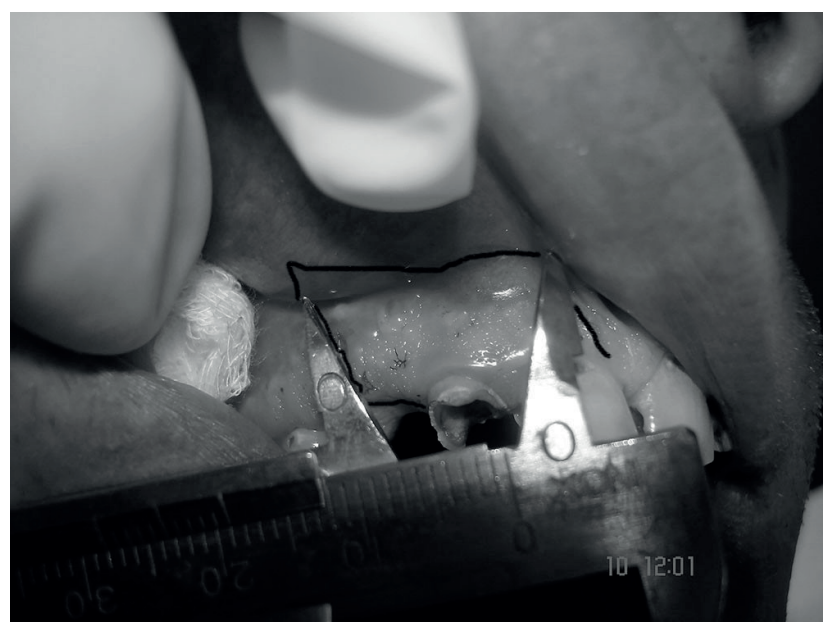

Fig. 1. The measuring procedure. 
Table 1. Socio-demographic characteristics of the study patients: the patients treated chronically by cardiovascular drugs; the patients without cardiovascular medication.

\begin{tabular}{|c|c|c|c|}
\hline \multirow[b]{2}{*}{ Variables } & \multicolumn{2}{|c|}{ Cardiovascular medication } & \multirow{2}{*}{$P$} \\
\hline & yes & no & \\
\hline Number of patients (\%) & $40(57.1)$ & $30(42.9)$ & \\
\hline \multicolumn{4}{|l|}{ Sex: } \\
\hline Male (\%) & $19(47.5)$ & $23(76.7)$ & \multirow{2}{*}{$P=0.027^{*}$} \\
\hline Female (\%) & $21(52.5)$ & $7(23.3)$ & \\
\hline Age; $\mathrm{M} \pm \mathrm{SD}$ & $56.38 \pm 8.22$ & $37.73 \pm 11.23$ & $P<0.001 * *$ \\
\hline Height $(\mathrm{cm}) ; \mathrm{M} \pm \mathrm{SD}$ & $170.30 \pm 10.67$ & $174.48 \pm 8.92$ & $P=0.095^{*} *$ \\
\hline Body weight $(\mathrm{kg}) ; \mathrm{M} \pm \mathrm{SD}$ & $77.78 \pm 14.05$ & $77.58 \pm 15.06$ & $P=0.812^{* *}$ \\
\hline Body mass index $\left(\mathrm{kg} / \mathrm{m}^{2}\right) ; \mathrm{M} \pm \mathrm{SD}$ : & $26.77 \pm 3.76$ & $24.58 \pm 6.37$ & $P=0.120 * *$ \\
\hline$<18.4(\%)$ & - & $2(6.7)$ & \multirow{4}{*}{$P=0.357^{*}$} \\
\hline $18.5-24.9(\%)$ & $16(40.0)$ & $12(40.0)$ & \\
\hline $25.0-29-9(\%)$ & $14(35.0)$ & $11(36.7)$ & \\
\hline$>30(\%)$ & $10(25.0)$ & $5(16.7)$ & \\
\hline \multicolumn{4}{|l|}{ Diagnosis: $(\%)$} \\
\hline Arterial hypertension & $33(82.5)$ & & \\
\hline Angina pectoris & $7(17.5)$ & & \\
\hline Heart failure & $14(35.0)$ & & \\
\hline Arrhythmias & $3(7.5)$ & & \\
\hline \multicolumn{4}{|l|}{ Cardiovascular medication (daily doses): (\%) } \\
\hline Beta blockers & $27(67.5)$ & & \\
\hline Bisoprolol $(2,5-5 \mathrm{mg})$ & $13(32.5)$ & & \\
\hline Metoprolol (25-100 mg) & $8(20)$ & & \\
\hline Karvedilol (12.5-25 mg) & $4(10)$ & & \\
\hline Propranolol hlorid (10 mg) & $2(5)$ & & \\
\hline ACE inhibitors & $24(60.0)$ & & \\
\hline Rampipril (2.5-20 mg) & $10(25)$ & & \\
\hline Enalaparil maleat (5-40 mg) & $5(12.5)$ & & \\
\hline Fosinopril (10-40 mg) & $4(10)$ & & \\
\hline Fosinopril, hidrohlortiazid (20 mg+12.5-40 mg+25) & $3(7.5)$ & & \\
\hline Enalapril, hidrohlortiazid (20 mg+25 mg) & $2(5)$ & & \\
\hline Calcium channel blockers & $15(37.5)$ & & \\
\hline Amlodipin (5-10 mg) & $11(27.5)$ & & \\
\hline Nifedipin (5-20 mg) & $2(5)$ & & \\
\hline Lerkanidipin (20 mg) & $1(2.5)$ & & \\
\hline Felodipin ( $5 \mathrm{mg}$ ) & $1(2.5)$ & & \\
\hline Vasodilatators & $5(12.5)$ & & \\
\hline Izosorbid 5 mononitrat (40 mg) & $2(5)$ & & \\
\hline Izosorbid dinitrat (40 mg) & $1(2.5)$ & & \\
\hline Dihidroergotoksin (4.5 mg) & $1(2.5)$ & & \\
\hline Pentaeritritil tetranitrat $(80 \mathrm{mg})$ & $1(2.5)$ & & \\
\hline Diuretics & $4(10.0)$ & & \\
\hline Bumetanid (1 mg) & $3(7.5)$ & & \\
\hline Spironolakton $(50 \mathrm{mg})$ & $1(2.5)$ & & \\
\hline Angiotensin receptor blockers & $4(10.0)$ & & \\
\hline Losartan (100 mg) & $2(5)$ & & \\
\hline Losartan, hidrohlortiazid (100 mg) & $2(5)$ & & \\
\hline Antiarrhythmics & $3(7.5)$ & & \\
\hline Propafenon hlorid (300 mg) & $2(5)$ & & \\
\hline Amjodaron (200 mg) & $1(2.5)$ & & \\
\hline Statins & $2(5.0)$ & & \\
\hline Pravastatin $(20 \mathrm{mg})$ & $1(2.5)$ & & \\
\hline Simvastatin $(10 \mathrm{mg})$ & $1(2.5)$ & & \\
\hline Alfa blockers & $1(2.5)$ & & \\
\hline Doksazosin $(8 \mathrm{mg})$ & $1(2.5)$ & & \\
\hline
\end{tabular}

*-chi-square test; M-mean; SD-standard deviation; **-Mann-Whitney U test 
Table 2. Distribution of diagnosis and duration of intervention in both groups.

\begin{tabular}{lccc}
\hline & \multicolumn{2}{c}{ Cardiovascular disease } & \\
Variables & yes & no & $P$ \\
\hline Diagnosis: & $22(55.0)$ & $21(70.0)$ & $P=0.114^{*}$ \\
$\quad$ Radix gangrenosa (\%) & $14(35.0)$ & $4(13.3)$ & \\
$\quad$ Periodontitis (\%) & $4(10.0)$ & $5(16.7)$ & $P=0.509^{*}$ \\
$\quad$ Parodontitis apicalis chronica exacerbate (\%) & & & \\
The duration of the intervention (in minutes): & $33(82.5)$ & $24(80)$ & $5(16.7)$ \\
$\quad$ <5 (\%) & $7(17.5)$ & $1(3.3)$ & \\
5-10 (\%) & - & & \\
$10-15(\%)$ & &
\end{tabular}

*-chi-square test

Table 3. Values of local anesthesia parameters in the study groups.

\begin{tabular}{|c|c|c|c|c|}
\hline & \multirow{2}{*}{ Variables; $\mathrm{M} \pm \mathrm{SD}$} & \multicolumn{2}{|c|}{ Cardiovascular disease } & \multirow{2}{*}{$P$} \\
\hline & & yes & no & \\
\hline \multirow{3}{*}{ 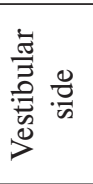 } & Time to onset of anaesthesia (in s) & $40.50 \pm 19.87$ & $58.93 \pm 31.07$ & $P=0.004^{*}$ \\
\hline & Time of the beginning of reduction of anesthetic area (in min) & $29.25 \pm 9.44$ & $37.14 \pm 9.76$ & $P<0.0001^{*}$ \\
\hline & $\begin{array}{l}\text { The duration of soft tissue anesthesia } \\
\text { (in min) }\end{array}$ & $55.00 \pm 16.07$ & $65.71 \pm 12.60$ & $P=0.007^{*}$ \\
\hline \multirow{3}{*}{$\frac{\pi}{\frac{\pi}{\pi}} \frac{0}{\pi}$} & Time to onset of anaesthesia (in s) & $49.74 \pm 39.01$ & $43.33 \pm 28.01$ & $P=0.311^{*}$ \\
\hline & Time of the beginning of reduction of anesthetic area (in min) & $24.72 \pm 7.36$ & $27.41 \pm 7.64$ & $P=0.092 *$ \\
\hline & The duration of soft tissue anesthesia (in min) & $39.14 \pm 14.43$ & $47.04 \pm 13.54$ & $P=0.033^{*}$ \\
\hline
\end{tabular}

M-mean; SD-standard deviation; *- Mann-Whitney U test

pending on whether the distribution of thdata was normal or not, which was checked by Kolmogorov-Smirnov test. Chi-square test was used to compare frequencies of categorical variables. For variables that were measured three times or more in the same group of respondents ANOVA for repeated measurements or Kruskal-Wallis test were used. Statistically significant results were the ones where the probability of the null hypothesis was less than 0.05 .

\section{RESULTS}

There were significantly more women in the cohort taking CVDs than in the control cohort $(P=0.027)$ (Table $1)$. Furthermore, the difference in the average age among groups was significant, the patients in the cohort taking CVDs were older $(P<0.001)$.

In regard to the cardiovascular therapy, the patients who had some of the cardiovascular diseases were using $2.38 \pm 1.34$ drugs on average and the therapy lasted from 3 to 5 years. Most of the patients were taking CVDs for over a year $(77.5 \%)$. The patients were taking the following cardiovascular drugs: beta blockers, angiotensin converting enzyme inhibitors, calcium channel blockers, vasodilatators, diuretics, angiotensin receptor blockers,antiarrhythmics, statins and alfa blockers. The daily doses of cardiovascular drugs used by the study patients and their diagnosis of cardiovascular diseases are shown in the Table 1.

The largest number of interventions in the group of subjects with cardiovascular therapy were on the incisors, while in the group of subjects without cardiovascular therapy there were significantly more frequent interventions on premolars $(P=0.025)$.

The most frequent indication for teeth extraction were residual tooth root and terminal stadium of periodontal disease. Tooth extraction intervention itself in most cases lasted less than $5 \mathrm{~min}$ (Table 2).

The parameters of local anesthesia between the study groups showed significant differences on the vestibular side, while the parameters on the palatal side differed only in duration of soft tissue anesthesia (Table 3 ). The onset of anesthesia on vestibular side was faster and duration of anesthesia on this side was shorter in the cohort taking CVDs. The anesthetized area on vestibular side started reducing earlier in the group of patients with cardiovascular therapy. Furthermore, all of the vestibular parameters were significantly different among the study groups (Table 3 ).

Table 4 presents the width and height of the anesthetized area in certain time measurements. The differences between the study groups in most of the measures were not significant, neither in the region of attached gingiva at palatal and at vestibular side, nor in the region of papillae.

It was shown that body mass index didn't affect onset of anesthesia, beginning of reduction of anesthetic area, duration of anesthesia and reduction of the width and height of anesthetic area on vestibular and palatal sides $(P>0.05)$.

In regard to the reduction of the height and width of the anesthetic area on vestibular and palatal sides, statistically significant difference between the two studied groups 
Table 4. Characteristics of the anesthetized area in the study groups.

\begin{tabular}{|c|c|c|c|c|}
\hline & \multirow{2}{*}{ Measurements } & \multicolumn{2}{|c|}{ Cardiovascular disease } & \multirow[b]{2}{*}{$P$} \\
\hline & & yes & no & \\
\hline \multirow{6}{*}{ 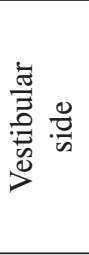 } & Width in $10 \mathrm{~min}$ (in $\mathrm{mm}$ ); $\mathrm{M} \pm \mathrm{SD}$ & $29.03 \pm 7.43$ & $26.29 \pm 7.53$ & $P=0.141^{*}$ \\
\hline & Width in $30 \mathrm{~min}$ (in $\mathrm{mm}$ ); $\mathrm{M} \pm \mathrm{SD}$ & $18.65 \pm 8.72$ & $20.43 \pm 7.13$ & $P=0.755^{*}$ \\
\hline & Width in $60 \mathrm{~min}$ (in $\mathrm{mm}$ ); $\mathrm{M} \pm \mathrm{SD}$ & $4.95 \pm 7.42$ & $7.46 \pm 7.65$ & $P=0.133^{*}$ \\
\hline & Height in $10 \mathrm{~min}$ (in $\mathrm{mm}$ ); $\mathrm{M} \pm \mathrm{SD}$ & $9.10 \pm 2.10$ & $9.93 \pm 1.81$ & $P=0.039 *$ \\
\hline & Height in $30 \mathrm{~min}$ (in $\mathrm{mm}$ ); $\mathrm{M} \pm \mathrm{SD}$ & $7.53 \pm 3.38$ & $9.29 \pm 1.84$ & $P=0.047^{*}$ \\
\hline & Height in $60 \mathrm{~min}$ (in $\mathrm{mm}$ ); $\mathrm{M} \pm \mathrm{SD}$ & $2.95 \pm 4.14$ & $5.07 \pm 4.59$ & $P=0.058^{*}$ \\
\hline \multirow{6}{*}{$\frac{\bar{\pi}}{\pi} \frac{\tilde{J}}{\pi}$} & Width in $10 \mathrm{~min}$ (in $\mathrm{mm}$ ); $\mathrm{M} \pm \mathrm{SD}$ & $16.33 \pm 7.97$ & $16.41 \pm .65$ & $P=0.631^{*}$ \\
\hline & Width in $30 \min ($ in $\mathrm{mm}$ ); $\mathrm{M} \pm \mathrm{SD}$ & $6.97 \pm 7.08$ & $10.37 \pm 10.09$ & $P=0.337^{*}$ \\
\hline & Width in $60 \mathrm{~min}$ (in $\mathrm{mm}$ ); $\mathrm{M} \pm \mathrm{SD}$ & $3.17 \pm 5.39$ & $5.93 \pm 8.23$ & $P=0.170^{*}$ \\
\hline & Height in $10 \mathrm{~min}$ (in $\mathrm{mm}$ ); $\mathrm{M} \pm \mathrm{SD}$ & $10.61 \pm 3.83$ & $11.85 \pm 3.44$ & $P=0.135^{*}$ \\
\hline & Height in $30 \mathrm{~min}$ (in $\mathrm{mm}$ ); $\mathrm{M} \pm \mathrm{SD}$ & $4.83 \pm 5.06$ & $7.19 \pm 4.90$ & $P=0.073^{*}$ \\
\hline & Height in $60 \mathrm{~min}$ (in $\mathrm{mm}$ ); $\mathrm{M} \pm \mathrm{SD}$ & $2.42 \pm 3.48$ & $4.19 \pm 4.65$ & $P=0.139 *$ \\
\hline \multirow{6}{*}{ 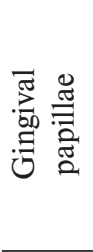 } & Vestibular side: & & & \multirow{4}{*}{$P=1.000^{* *}$} \\
\hline & Yes $(\%)$ & $39(97.5)$ & $27(96.4)$ & \\
\hline & No (\%) & $1(2.5)$ & $1(3.6)$ & \\
\hline & Palatal side: & & & \\
\hline & Yes (\%) & $28(73.7)$ & $21(77.8)$ & \multirow{2}{*}{$P=0.932 * *$} \\
\hline & No (\%) & $10(26.3)$ & $6(22.2)$ & \\
\hline
\end{tabular}

M-mean; SD- standard deviation; *-Mann-Whitney U test; **-chi-square test

Table 5. Percentage of the decrease of anesthetic area in both groups depending on the first measuring.

\begin{tabular}{|c|c|c|c|c|}
\hline & \multirow[t]{2}{*}{ Measurements; $\mathrm{M} \pm \mathrm{SD}$} & \multicolumn{2}{|c|}{ Cardiovascular disease } & \multirow{2}{*}{$P$} \\
\hline & & yes & no & \\
\hline \multirow{6}{*}{ 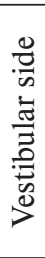 } & Width in $10 \mathrm{~min}$ (in $\mathrm{mm}$ ) & - & - & - \\
\hline & Width in $30 \mathrm{~min}$ (in $\mathrm{mm}$ ) & $36.25 \pm 26.63$ & $20.39 \pm 23.18$ & $P=0.053^{*}$ \\
\hline & Width in $60 \mathrm{~min}$ (in $\mathrm{mm}$ ) & $83.89 \pm 23.39$ & $72.67 \pm 26.97$ & $P=0.069^{*}$ \\
\hline & Height in $10 \mathrm{~min}$ (in $\mathrm{mm}$ ) & - & - & - \\
\hline & Height in $30 \mathrm{~min}$ (in $\mathrm{mm}$ ) & $17.63 \pm 33.63$ & $5.26 \pm 17.11$ & $P=0.639^{*}$ \\
\hline & Height in $60 \mathrm{~min}$ (in $\mathrm{mm}$ ) & $70.39 \pm 42.03$ & $48.91 \pm 50.68$ & $P=0.157^{*}$ \\
\hline \multirow{6}{*}{$\begin{array}{l}\frac{\pi}{0} \\
\frac{\pi}{\pi} \\
\frac{\vec{\pi}}{\pi} \\
0\end{array}$} & Width in $10 \mathrm{~min}$ (in $\mathrm{mm}$ ) & - & - & - \\
\hline & Width in $30 \mathrm{~min}$ (in mm) & $61.52 \pm 36.50$ & $45.27 \pm 33.50$ & $P=0.085^{*}$ \\
\hline & Width in $60 \mathrm{~min}$ (in $\mathrm{mm}$ ) & $83.28 \pm 27.06$ & $74.83 \pm 29.60$ & $P=0.212^{*}$ \\
\hline & Height in $10 \mathrm{~min}$ (in $\mathrm{mm}$ ) & - & - & - \\
\hline & Height in $30 \mathrm{~min}$ (in $\mathrm{mm}$ ) & $52.02 \pm 45.68$ & $42.96 \pm 34.39$ & $P=0.605^{*}$ \\
\hline & Height in $60 \mathrm{~min}$ (in $\mathrm{mm}$ ) & $74.59 \pm 37.19$ & $67.13 \pm 35.51$ & $P=0.336^{*}$ \\
\hline
\end{tabular}

M-mean; SD-standard deviation; *-Mann-Whitney U test

was not observed (Table 5). However, it was evident that in all measured time sections between the study groups, anesthetized area (width and height of the palatal and vestibular) dissipated more rapidly in the group of subjects who were on the cardiovascular therapy than in the group of subjects without cardiovascular therapy (Table 5).

Regarding the number of used cardiovascular drugs and their effects on the size of the anesthetic area on vestibular side, it was shown that no statistically significant difference was found $(P>0.05)$, while on palatal side there was statistically significant difference on the width of the anesthetic area in the $10^{\text {th }}$ and $30^{\text {th }}$ min and the height in the $30^{\text {th }}$ min.

The duration of cardiovascular therapy made significant impact on the anesthetized area in the group of subjects who were taking cardiovascular drugs, especially on the width of the anesthetic area in the $60^{\text {th }}$ min on the vestibular side as well as on the height in the $30^{\text {th }}$ and $60^{\text {th }}$ min (it was the largest in the group in which the treatment lasted less than a year, while average value was smaller in other groups). In case of palatal anesthetic area the significant difference was not found in any of the parameters regarding the length of the cardiovascular therapy.

Referring to the duration of the intervention the significant differences in the size of anesthetic areas between the two studied groups were not found.

\section{DISCUSSION}

The most important findings of our study were that local anesthesia used for dental extraction had shorter duration, and that dissipation of the anesthetic area was more rapid in the group of patients taking cardiovascular 
drugs. Such results were not observed previously, because the studies of similar design were not conducted. Majority of previous studies were limited to monitoring the impact of local anesthesia on the hemodynamic parameters of cardiovascular patients ${ }^{11}$. Local clinical parameters of anesthesia were monitored only in healthy subjects through comparative analysis of two different anesthetics given by the same anesthetic technique or two different anesthetic techniques using the same anesthetic ${ }^{12,13}$. Two in vitro studies have recently demonstrated that antihypertensives propranolol and verapamil cause local anesthe$\mathrm{sia}^{14,15}$. A few preclinical studies showed that duration of local anesthesia is prolonged after concurrent administration of anesthetics and certain cardiovascular drugs ${ }^{16}$. Intramuscular administration of propranolol in masseter muscle of volonteers reduced the pain caused by intramuscular injection of serotonin, as shown in the study of Ernberg et al. ${ }^{17}$. On the other hand, Charles et al. ${ }^{18}$ showed that subcutaneous coadministration of verapamil and lidocaine shortened duration of local anesthesia in comparison to the lidocaine only.

Propranolol demonstrates local anesthetic effect comparable to that of lidocaine by decreasing sodium and calcium influx ${ }^{19}$. The decrease of neuronal excitability and nociception caused by $\beta$-adrenergic receptors blockers was also proved, associated with suppression of voltage sensitive calcium and sodium channels activity reduction of intracellular cyclic adenosine monophosphate ${ }^{19}$ levels and decrease of the adenylcyclase ${ }^{20}$ activity. Furthermore, $\beta$-blockers inhibit phospholipase A (ref. ${ }^{21}$ ) leading to reduction of interleukin-6 (ref. ${ }^{22}$ ) and tumor necrosis factor- $\alpha$ (ref. $\left.{ }^{23}\right)$ release. All these actions are strongly related to analgesia ${ }^{24}$.

Taking into account the mechanism of action of cardiovascular drugs ${ }^{5}$, we assume that the more rapid onset of anesthesia in the group of cardiovascular patients was due to potentiation of effects of local anesthetics by the cardiovascular drugs. Although in our study the anesthetized area was not different among the groups, local anesthesia started earlier, dissipated more rapidly and lasted shorter in the patients with chronic cardiovascular therapy. In the study of Charles and associates ${ }^{18}$ about the subcutaneous application of verapamil and lidocaine on volar forearm compared to lidocaine itself it was shown that duration of action of anesthesia was shorter after coadministration of the two drugs. This result could have been caused by vasodilating effect of verapamil causing local erythema and/or edema, physicochemical reactions with lidocaine, or both; both actions can decrease bioavailability of lidocaine ${ }^{18}$. Like in this study, systemically administered anti-hypertensive drugs with universal vasodilating properties in our study caused significantly shorter duration of anesthesia in groups of patients who were on chronic cardiovascular therapy.

In contrast to our results, the preclinical study of $\mathrm{Yu}$ Chen Wen et al. ${ }^{16}$ showed that the coadministration of propranolol and lidocaine compared to lidocaine alone led to the longer duration of cutaneous analgesia in rats. Study of Hyer et al. ${ }^{25}$ implied that $\beta$-receptor antagonists (propranolol) may also reduce skin blood flow and help extend the duration of anesthetic action, decrease local blood loss and restrict systemic absorption, too. Also, the other preclinical studies of Yu-Wen Chen et al. ${ }^{26}$ showed that coadministration of propranolol and lidocaine provided longer spinal anesthesia.

In a study on animal models by Keiichi et al. ${ }^{27}$ concurrent administration of a calcium channel blocker (verapamil) with lidocaine prolonged spinal anesthesia, compared to use of lidocaine only. In preclinical research of Iwasaki et al. ${ }^{28}$ it was confirmed that drugs blocking calcium channels of L-type (verapamil, diltiazem and nicardipine) in combination with lidocaine increase degree and duration of local lidocaine sensory block in rats. However, we should emphasize that local administration of verapamil increases toxicity of local anesthetics ${ }^{29}$.

In a study of Forest et al. ${ }^{30}$ it was shown that nifedipine significantly increased duration of anesthesia and potency of local anesthetic bupivacaine. Hence, L-type calcium channels on nociceptors and skin seem to be very important factor in regulating duration and intensity of infiltrative local anesthesia in mice ${ }^{30}$.

A few studies on rats showed that locally administered calcium channel blockers and beta blockers produce dosedependent analgesia in rats ${ }^{14,16}$. In our study, number of cardiovascular drugs used was not associated with size of the anesthetized area. On the other hand, cardiovascular therapy that lasted longer than one year was associated with accelerated dissipation of the anesthetic effect on vestibular side. This influence of cardiovascular drugs could be explained by down-regulation of beta-adrenergic and some other receptors and ion channels provoked by continuous presence of the cardiovascular drugs (e.g. beta-blockers) in blood and tissues.

An interesting approach to decrease adverse influences of cardiovascular drugs on effects and possible toxicity of local anesthetics was proposed by Krikava and associates $^{31}$, who showed that combining local anesthetics with antiarrhytmic properties (lidocaine and bupivacaine) may decrease adverse influence on cardiac conductivity.

The limitation of this study was the age difference between these two study groups. As the cardiovascular disease occurs more often in elderly, this could not be avoided. However, the correlation between the age and duration of soft tissue anesthesia in our study was weak (Spearman's correlation coefficient was -0.285), suggesting that the age did not significantly affect the parameters of local anaesthesia in CVDs group.

\section{CONCLUSION}

In conclusion, drugs acting on cardiovascular system may have influence on effects of local anesthetics used in dentistry, possibly through interaction at autonomic receptors and ion channels. When a dentist encounter a patient taking cardiovascular medication chronically, he or she should be prepared for possible shorter action of local anesthetics and be ready to add more of local anesthetic during long and extensive dental interventions. 
Author contribution: All authors contributed equally to preparing the manuscript.

Conflict of interest statement: The authors state that there are no conflicts of interest regarding the publication of this article.

\section{REFERENCES}

1. Scholz A. Mechanisms of (local) anaesthetics on voltage-gated sodium and other ion channels. Br J Anaesth 2002;89(1):52-61.

2. Skjevik $A A$, Haung $B E$, Lygre $H$, Teigen $K$. Intramolecular hydrogen bonding in articaine can be related to superior bone tissue penetration: a molecular dynamics study. Biophys Chem 2011;154(1):18-25.

3. Lima-Júnior JL, Dias-Ribeiro E, de Araújo TN, Ferreira-Rocha J, HonfiJúnior ES, Sarmento CF, Seabra FR, de Sousa Mdo S. Evaluation of the buccal vestibule-palatal diffusion of $4 \%$ articaine hydrochloride in impacted maxillary third molar extractions. Med Oral Patol Oral Cir Bucal 2009;14(3):E129-32.

4. Hersh EV, Giannakopoulos H, Levin LM, Secreto S, Moore PA Peterson C, Hutcheson M, Bouhajib M, Mosenkis A, Townsend RR. The pharmacokinetics and cardiovascular effects of high-dose articaine with 1:100,000 and 1:200,000 epinephrine. J Am Dent Assoc 2006; 137(11):1562-71.

5. Tzeng Jl, Cheng KI, Huang KL, Chen YW, Chu KS, Chu CC, Wang JJ. The cutaneous analgesic effect of class I antiarrhythmic drugs. Anesth Analg 2007;104(4):955-8.

6. Zimmermann AP, Wiegand S, Werner JA, Eivazi B. Propranolol therapy for infantile haemangiomas: review of the literature. Int J Pediatr Otorhinolaryngol 2010;74(4):338-42.

7. Serrera Figallo MA, Velázquez Cayón RT, Torres Lagares D, Corcuera Flores JR, Machuca Portillo G. Use of anesthetics associated to vasoconstrictors for dentistry in patients with cardiopathies. Review of the literature published in the last decade. J Clin Exp Dent 2012;4(2):e107-11.

8. Brković B, Gardašević M, Roganović J, Jović N, Todorović Lj, Stojić D. Lidocaine+clonidine for maxillary infiltration anaesthesia: parameters of anaesthesia and vascular effects. Int J Oral Maxillofac Surg 2008;37(2):149-55.

9. Brković B, Zlatković M, Jovanović D, Stojić D. Maxillary infiltration anaesthesia by ropivacaine for upper third molar surgery. Int.J Ora Maxillofac Surg 2010;39(1):36-41.

10. Faul F, Erdfelder E, Lang AG, Buchner A. G*Power 3: a flexible statistical power analysis program for the social, behavioral, and biomedical sciences. Behav Res Methods 2007;39(2):175-91.

11. Torres-Lagares D, Serrera-Figallo MÁ, Machuca-Portillo G, CorcueraFlores JR, Machuca-Portillo C, Castillo-Oyagüe R, Gutiérrez-Pérez JL. Cardiovascular effect of dental anesthesia with articaine $(40 \mathrm{mg}$ with epinefrine $0,5 \mathrm{mg} \%$ and $40 \mathrm{mg}$ with epinefrine $1 \mathrm{mg} \%$ ) versus mepivacaine (30 mg and $20 \mathrm{mg}$ with epinefrine $1 \mathrm{mg} \%$ ) in medically compromised cardiac patients: a cross-over, randomized, single blinded study. Med Oral Patol Oral Cir Bucal 2012;17(4):e655-60.

12. Brkovic BM, Savic M, Andric M, Jurisic M, Todorovic Lj. Intraseptal vs. periodontal ligament anaesthesia for maxillary tooth extraction: quality of local anaestesia and hemodynamic response. Clin Ora Invest 2010;14(6):675-81.

13. Kanaa MD, Whitworth JM, Meechan JG. A comparison of the efficacy of $4 \%$ articaine with 1:100,000 epinephrine and $2 \%$ lidocaine with $1: 80,000$ epinephrine in achieving pulpal anesthesia in maxillary teeth with irreversible pulpitis. J Endod 2012;38(3):279-82.

14. Chen YW, Chu CC, Chen YC, Wang JJ, Hung CH. The dose-dependent study of verapamil and diltiazem on spinal anesthesia in the rat. Neurosci Lett 2010;482(1):76-80.

15. Chen YW, Chu CC, Chen YC, Hung CH, Wang JJ. Intrathecal propranolol displays long-acting spinal anesthesia with a more sensory-selective action over motor blockade in rats. Eur J Pharmacol 2011;667(1-3):208-14

16. Chen YW, Chu CC, Chen YC, Hung CH, Wang JJ. Propranolol elicits Cutaneous analgesia against skin nociceptive stimuli in rats. Neurosci Lett 2012;524(2):129-32.

17. Ernberg M, Lundeberg T, Kopp S. Effect of propranolol and granisetron on experimentally induced pain and allodynia/hyperalgesia by intramuscular injection of serotonin into the human masseter muscle. Pain 2000;84(2-3):339-46.

18. Laurito CE, Cohn SJ, Becker GL. Effects of subcutaneous verapamil on the duration of local anesthetic blockade. J Clin Anesth 1994;6(5):414-8.

19. Akaike $\mathrm{N}$, Ito $\mathrm{H}$, Nishi $\mathrm{K}$, Oyama Y. Further analysis of inhibitory effects of propranolol and local anaesthetics on the calcium current in Helix neurones. Br J Pharmacol 1982;76(1):37-43.

20. Taussig R, Gilman AG. Mammalian membrane-bound adenylyl cyclases. J Biol Chem 1995;270(1):1-4.

21. Trotz M, Jellison EJ, Hostetler KY. Propranolol inhibition of the neutral phospholipases A of rat heart mitochondria, sarcoplasmic reticulum and cytosol. Biochem Pharmacol 1987;36(24):4251-6.

22. Soszynski D, Kozak W, Conn CA, Rudolph K, Kluger MJ. Betaadrenoceptor antagonists suppress elevation in body temperature and increase in plasma IL- 6 in rats exposed to open field. Neuroendocrinology 1996;63(5):459-67.

23. Bloksma N, Hofhuis F, Benaissa-Trouw B, Willers J. Endotoxin-induced release of tumour necrosis factor and interferon in vivo is inhibited by prior adrenoceptor blockade. Cancer Immunol Immunother 1982;14(1):41-5.

24. Millan MJ. The induction of pain: an integrative review. Prog Neurobiol 1999;57(1):1-164.

25. Hyer SL, Taylor D, Barham J, Wilson J, Shaw J, Vince FP. The effects of propranolol and metoprolol on skin blood flow in diabeticpatients. Br J Clin Pharmacol 1987;23(6):769-71.

26. Chen YW, Chu CC, Chen YC, Hung CH, Li YT, Wang JJ. Lidocaine for prolonged and intensified spinal anesthesia by coadministration of propranolol in the rat. Neurosci Lett 2011;503(1):63-7.

27. Omote $K$, Iwasaki $H$, Kawamata M, Satoh O, Namiki A. Effects of verapamil on spinal anesthesia with local anesthetics. Anesth Analg 1995;80(3):444-8.

28. 28Iwasaki H, Ohmori H, Omote K, Kawamata M, Sumita S, Yamauchi $M$, Namiki A. Potentiation of local lignocaine induced sensory block by calcium channel blockers in rats. Br J Anaesth 1996;77(2):243-7.

29. Tallman RD Jr, Rosenblatt RM, Weaver JM, Wang YL. Verapamil increases the toxicity of local anesthetics. J Clin Pharmacol 1988;28(4):317-21.

30. Smith FL, Davis RW, Carter R. Influence of Voltage-sensitive $\mathrm{Ca}(++)$ channel drugs on bupivacaine infiltration anesthesia in mice. Anesthesiology 2001;95(5):1189-97.

31. Krikava I, Jarkovský J, Stourac P, Nováková M, Sevcík P. The effects of lidocaine on bupivacaine-induced cardiotoxicity in the isolated rat heart. Physiol Res 2010;59 Suppl 1:S65-9 